\title{
BMJ Global Health The implicit ideological function of the global health field and its role in maintaining relations of power
}

\author{
Hani Kim
}

To cite: Kim H. The implicit ideological function of the global health field and its role in maintaining relations of power. BMJ Global Health 2021;6:e005620. doi:10.1136/ bmjgh-2021-005620

Handling editor Seye Abimbola

Received 6 March 2021 Revised 1 April 2021 Accepted 1 April 2021

\section{Check for updates}

(c) Author(s) (or their employer(s)) 2021. Re-use permitted under CC BY-NC. No commercial re-use. See rights and permissions. Published by BMJ.

Global Health, Bill \& Melinda Gates Foundation, Seattle, Washington, USA

Correspondence to

Dr Hani Kim;

hanikim584@gmail.com

\section{INTRODUCTION}

One formidable barrier to equity in the global health field is its implicit function of legitimising and reproducing the existing power structure in addition to its explicit goal of improving population health and health equity.

In October 2019, the Johns Hopkins Bloomberg School of Public Health, Nuclear Threat Initiative, and the Economist Intelligence Unit published the Global Health Security Index. ${ }^{1}$ An international advisory panel of '21 experts from 13 countries ranked 195 countries based on a comprehensive framework of 140 questions, organized across 6 categories, 34 indicators, and 85 subindicators to assess a country's capability to prevent and mitigate epidemics and pandemics'. The USA, the UK and the Netherlands were ranked top 3 countries on the overall score, with the USA ranked first in four out of the six categories, which were prevention, detection and reporting, rapid response, health system, compliance with international norms, and risk environment. ${ }^{1}$ As of 8 February 2021, the UK and the USA show the fourth and the ninth highest numbers of cumulative COVID-19 deaths per million people, respectively. $^{2}$

Analysing the reasons why the index failed is not my objective. The point to observe is that indices such as this perform an implicit function of structuring and legitimising the relations of power regardless of their success or failure. This is the function of ideology. Had the pandemic not invalidated the index, the index would still have shaped meaning and value we assign to 'pandemic preparedness' in line with existing relations of power among nations. Ideology governs our reasoning and hierarchy of our knowledge, values and beliefs. ${ }^{34}$ It ultimately serves and naturalises hegemonic values.
Summary box

In an unequal and unjust society, every field of study performs an implicit ideological function of legitimising and reproducing the existing power structure in addition to its explicit goal.

- Throughout its history, global health practice has not only been shaped by the hegemonic values of each epoch, but also it has actively advanced and served them at an implicit level regardless of its explicit function to improve population health.

- One formidable barrier to solving global health inequities is that this implicit ideological function is kept hidden from view and critical enquiry, and thus invisibly limits what we observe and what we imagine to be possible.

- Previous studies have critiqued particular ideological contents, such as racism or colonialism, as sources of power asymmetry in global health.

- Critiques of particular ideological contents, while necessary, are not sufficient in revealing how ideology operates through the implicit in the doing.

- Envisioning new directions, ideas and allies to solve health inequities rooted in relations of power requires making visible how ideology operates implicitly in global health.

In a society with inequalities, every social domain is subject to a pressure to legitimise the prevailing social order. This ideological function is constitutive to the system of inequalities and permeates throughout the entire social body. ${ }^{56}$ It is not something that a field of study can 'opt out' of, or something that can be evaded with experts or indicators. The choice we face is whether to obfuscate this implicit ideological function or to make it visible. When we collectively confront the injustice inherent in the system, and our inextricable role in sustaining it, we can see new directions and new allies in our collective action to move the field towards greater equity beyond cosmetic changes. 


\section{THE IDEOLOGICAL FUNCTION OF GLOBAL HEALTH}

The global health field has performed an implicit ideological function throughout its history. ${ }^{7}$ Beginning as 'tropical medicine' in the $1800 \mathrm{~s}$, it was founded on a system of extracting and exploiting resources and labour of the Global South by the European and American colonial nations. ${ }^{89}$ The need to protect colonial nations' commercial interests from the threat of infectious diseases served as a powerful impetus to advance the field of microbiology and modern medicine, with seminal discoveries of the aetiological agents of the major infectious diseases at the time, including cholera (1854), malaria (1880), tuberculosis (1882) and targeted treatments (eg, quinine to treat malaria in 1897). ${ }^{10-12}$ This period also saw the establishment of the earliest global health institutes of education and research (eg, the Liverpool School of Tropical Medicine (1893), the London School of Hygiene and Tropical Medicine (1894), the Walter Reed Army Institute of Research (1893)). ${ }^{13-15}$ They remain leading institutes of global health research today.

The knowledge generated during the era of 'tropical medicine' contributed significantly to improving population health (explicit function). Simultaneously, the knowledge contributed to protecting the interests of the colonising nations, and implicitly legitimised the power relations between the colonising and the colonised nations. The growth of the field is inseparable from the ascendancy of the values espoused in the 'germ theory', and 'magic bullet' from this era, which were to become the normative framework around causes of and solutions to ill health globally.

During the Cold War (1946-1979), global health, then described as 'international health', was caught in a hegemonic battle between the USA and the Soviet Union and faced competing visions of the market-delivered health services championed by the USA, the centralised, state-led provision of primary healthcare championed by the Soviet Union, and the community-driven, government-led 'health for all' approach aspired mainly by the countries of the Non-Aligned Movement. ${ }^{16} 17$ Collapse of the Soviet Union and the Eastern Bloc in 1989-1991 and rise of the USA as the world's sole superpower established the dominance of its neoliberal values, which were to shape global health practice and knowledge production until today.

Global health implicitly advances and legitimises the hegemony of neoliberal values in its tendency to individualise and depoliticise causes of and solutions to ill health and health inequities. ${ }^{718}$ This tendency prioritises individual-level biological causes or risk factors, which lend themselves as desirable targets of interventions that are detached from the broader context of political economy, ${ }^{19-21}$ and accordingly is associated with a disproportionate emphasis on technological solutions.

Certainly, technological solutions such as vaccines, diagnostics and drugs are life-saving and contribute to improving population health. The problem is not something intrinsic to technological solutions, but the dominance of this approach in attracting most funding, most publications and most recognition. It limits multiplicity of viewpoints, approaches and insights, and legitimises concentrating resources and privileges within individuals and institutions that are most aligned with and benefit from advancing the dominant approaches.

Within the neoliberal framing of health as individual, apolitical and technical, there is little room to interrogate power, for power is inherently a relational and a political concept. Irrespective of the legitimate merits of life-saving interventions generated from the neoliberal framing of health, global health practice implicitly obfuscates the relations of power that undergird global health inequities.

Throughout its history, global health practice has not only been shaped by the hegemonic values of each epoch, it has also actively advanced and served them at an implicit level regardless of its explicit function to improve population health. While the explicit function and its achievements are rigorously tracked and regularly celebrated, this implicit ideological function is kept hidden from critical scrutiny, and invisibly maintains the existing power structure in the field.

\section{OPERATION OF IDEOLOGY THROUGH THE IMPLICIT}

Solving the much talked about 'power imbalances' in global health requires making visible the implicit ideological function that the field performs. However, ideological function is difficult to discern because ideology operates through the implicit, not through explicitly stated beliefs or intent. ${ }^{22}$ To my knowledge, no global health institution has an explicit mission of concentrating wealth and power within itself, or to serve the hegemonic value of its time. Ideological function is not found in organisational mission statements or in research proposal documents. Critiques of ideology should be directed at what is implicit in the doing, ${ }^{22} 23$ and how the doing relates to the existing power structure.

Global health programmes implicitly perform ideological function in two prominent ways: first, by providing an avenue for the global elites to discipline and control the non-elite countries and people; and second, by providing a sense of relief or redemption for (mostly European and North American, but really global) elites through acting out of 'charitable' impulses or fulfilling a sense of 'moral duty'.

The first is rooted in an assumed sense of racial, intellectual or cultural superiority, and can be traced back to racialised global health practices in the 19th century, which were justified as fulfilling a moral duty of the colonising nations to 'civilize' the 'primitive' peoples of colonised nations and territories. ${ }^{824}$

The second is not unrelated to the first. The sense of redemption offered by the narrative of charity fundamentally reframes the relation between the privileged and the marginalised. Inequality is a relational concept. Conditions that concentrate resources and power in the 
privileged are the very conditions that permit deprivation of the marginalised within and between countries. In these relational terms, deprivation of wealth and power from the marginalised is a necessary consequence, not an accident, of a system contingent on concentrating wealth and power.

Within the narrative of charity, this immanent tension in the relation between the privileged and the marginalised is obscured. The conditions that serve the interests of the privileged are portrayed as if they are delinked from the conditions that deprive the marginalised. The inherent tension between the two as a structural necessity is obscured, and their relation is recast with the gaze of charity or moral responsibility. The privileged are now exempt from the causal process underlying the deprivation of the marginalised. The privileged are then offered a sense of relief and redemption from acting out of charitable impulses or fulfilling their sense of moral duty. Ideology operates at this implicit level.

For example, the mission statement of the Gates Foundation, the largest private philanthropy in the global health field, is 'All lives have equal value'. ${ }^{25}$ While there are undeniable merits and contributions made by programmes and research supported by the Gates Foundation, the existence and flourishing of large private philanthropies are predicated on extreme concentration of wealth globally. ${ }^{26} 27$ Inequality in the ownership and control of resources is a structural necessity for producing large private philanthropies like the Gates Foundation, Chan Zuckerberg Foundation or Aliko Dangote Foundation. The argument that economic inequalities are justified based on individual merits and that these inequalities serve social benefits has not withstood scrutiny. ${ }^{28}$

While explicit justifications for economic inequalities have failed scrutiny, global health practice offers a venue to implicitly legitimise them. As a field whose explicit mission of saving lives is undeniably virtuous, global health serves as a perfect platform for ideological operation.

\section{CONCLUSION}

Ideology functions to naturalise and maintain prevailing relations of power. Recent debates about power imbalances in global health have urged the field to contest 'all forms of supremacy', 'to become actively antisupremacist, and also anti-oppressionist and anti-racist' in order 'to transcend its origin'. ${ }^{29-31}$ This is a necessary step for transforming the field towards greater equity. But it is not enough. Critiquing particular ideological contents does not address how ideology operates. Without understanding and critiquing how ideology operates, we risk losing sight of new narratives in the making to legitimise inequalities.

As I am writing this article as an employee at the Gates Foundation, my own critical self-reflection gives rise to a sense of unease from recognising the inherent contradiction in my privileged position. No amount of writing about the ideological function of the field will 'cancel out' this conflict, and that is precisely the point: to confront the unease in recognising the injustice embedded in the structure, and my own inextricable role in it. Denying this conflict with 'but I am doing my part' obscures my role in perpetuating the structure of injustice. My intent is irrelevant. What matters is what is implicit in my doing.

Let us 'do our part' but let us not fall for an illusion that it is possible to escape the ideological pressure and conditioning which are inherent in an unequal and unjust society. That may sound pessimistic, but it is far from it. The point is to confront ideology and make it visible. Solidarity is unimaginable otherwise. Spaces for shared struggle open when we collectively confront the injustices inherent in the system, and our role in sustaining it. When we make visible this implicit ideological function that global health field performs, we can see new directions, new ideas and new allies for collective action that are otherwise kept unimaginable.

Twitter Hani Kim @HaniKim_hk

Acknowledgements I am grateful to Uros Novakovic, an architect at Office $0 \mathrm{u}$, Toronto, Canada, for an extensive discussion throughout the conceptualising and writing of the manuscript. I thank Dr Resham Khatri at the University of Queensland, Australia, and Russell Christenson, an independent researcher in Seattle, USA, for their review of the manuscript and feedback.

Collaborators Uros Novakovic

Contributors HK conceptualised, conducted the research and wrote the manuscript

Funding The authors have not declared a specific grant for this research from any funding agency in the public, commercial or not-for-profit sectors.

Disclaimer Views expressed in this article are the author's alone, and do not represent views, interests or funded work of the Bill \& Melinda Gates Foundation.

Competing interests None declared.

Patient consent for publication Not required.

Provenance and peer review Not commissioned; internally peer reviewed.

Data availability statement There are no data in this work.

Open access This is an open access article distributed in accordance with the Creative Commons Attribution Non Commercial (CC BY-NC 4.0) license, which permits others to distribute, remix, adapt, build upon this work non-commercially, and license their derivative works on different terms, provided the original work is properly cited, appropriate credit is given, any changes made indicated, and the use is non-commercial. See: http://creativecommons.org/licenses/by-nc/4.0/.

\section{ORCID iD}

Hani Kim http://orcid.org/0000-0001-5963-4305

\section{REFERENCES}

1 Johns Hopkins Bloomberg School of Public Health, Nuclear Threat Initiative. Global health security index, 2019. Available: https://www. ghsindex.org/wp-content/uploads/2020/04/2019-Global-HealthSecurity-Index.pdf [Accessed 7 Feb 2021].

2 Our world in data. coronavirus pandemic data explorer. Available: https://ourworldindata.org/coronavirus [Accessed 2 Aug 2021].

3 Žižek S. The spectre of ideology. In: Mapping ideology. London: Verso, 2012: 1-33.

4 Eagletone T. What is ideology? In: Ideology:an introduction. London: Verso, 2007: 1-31.

5 Foucault M. Truth and power. In: Gordon C, ed. Power/knowledge: selected interviews and other writings, 1972-1977. Pantheon Books, 1980.

6 Hegemony JS. Antonio Gramsci. New York: Routledge, 2006: 40-56. 
$7 \mathrm{Kim} \mathrm{H}$, Novakovic U, Muntaner C, et al. A critical assessment of the ideological underpinnings of current practice in global health and their historical origins. Glob Health Action 2019;12:1651017.

8 Greene J, Basilico M, Kim H, et al. Colonial medicine and its legacies. In: Farmer P, Kim J, Basilico M, eds. Reimagining global health. Berkeley: University of California Press, 2013: 33-73.

9 Birn A-E, Pillay Y, Holtz TH. The historical origins of modern international (and global) health. In: Birn A-E, Pillay Y, Holtz T, eds. Textbook of global health. 4th edn. New York: Oxford University Press, 2017: 1-42.

10 Webb J. Toward global public health: a trio of discoveries in 1897. In: Humanity's burden: a global history of malaria. Cambridge: Cambridge University Press, 2009: 128-9.

11 Lippi D, Gotuzzo E. The greatest steps towards the discovery of Vibrio cholerae. Clin Microbiol Infect 2014;20:191-5.

12 Sakula A. Robert Koch: centenary of the discovery of the tubercle Bacillus, 1882. Can Vet $J=$ La Rev Vet Can 1983;24:127-31.

13 LSTM. Liverpool school of tropical medicine: history. Available: https://www.Istmed.ac.uk/about/history [Accessed 2 Mar 2019].

14 LSHTM. London school of hygiene and tropical medicine: history. Available: https://www.Ishtm.ac.uk/aboutus/introducing/history [Accessed 2 Mar 2019].

15 WRAIR. Walter reed army Institute of research: a brief history. Available: https://www.defensemedianetwork.com/stories/walterreed-army-institute-of-research-a-brief-history/

16 Birn A-E, Pillay Y, Holtz TH. Between international and global health: Contextualizing the present. In: Textbook of global health. 4th edn. New York, NY: Oxford University Press, 2017: 65-6.

17 The USSR Ministry of Health. 1979 who archive: health for all, as defined in the Alma Ata conference. U.S.S.R: Kazakh film, 1979. Available: https://www.youtube.com/watch?v=qHcw2HPhw0s

18 Harvey D. The neoliberal state. In: A brief history of neoliberalism. New York: Oxford University Press, 2005: 66-8.
19 Muntaner $\mathrm{C}, \mathrm{Ng} \mathrm{E}$, Chung $\mathrm{H}$, et al. Two decades of Neo-Marxist class analysis and health inequalities: a critical reconstruction. Soc Theory Health 2015;13:267-87.

20 Brandt AM. Behavior, disease, and health in the twentiethcentury United States the moral valence of individual risk. In: Brandt A, Rozin P, eds. Morality and health. New York: Routledge, 1997: 53-78.

21 Muntaner $\mathrm{C}$, Chung $\mathrm{H}$. Commentary: macrosocial determinants, epidemiology, and health policy: should politics and economics be banned from social determinants of health research? J Public Health Policy 2008;29:299-306.

22 Novakovic U. Emphasize the gap towards a Žižekian definition of critical-emancipatory architecture, 2013.

23 Žižek S. The sublime object of ideology. London: Verso, 2008.

24 Piketty T. Colonial societies: diversity and domination. In: Capital and ideology. 270. Cambridge, MA: The Belknap Press of Harvard University Press, 2019

25 Bill \& Melinda Gates Foundation. Available: https://www. gatesfoundation.org/ [Accessed 8 Feb 2021].

26 Chow H, Dahl M, Dearden N. Gated development, 2016.

27 Aschoff N. The Gates Foundation and the rise of philanthrocapitalism. In: The new prophets of capital. Brooklyn: Verso, 2015: 107-43.

28 Piketty T. From the philanthropic illusion to the sacrilization of billionaires. In: Capital and ideology. Cambridge, MA: The Belknap Press of Harvard University Press, 2019: 713-6.

29 Abimbola S, Pai M. Will global health survive its decolonisation? Lancet 2020;396:1627-8.

30 Abimbola S. The foreign gaze: authorship in academic global health. BMJ Glob Health 2019;4:e002068-5.

31 Büyüm AM, Kenney $C$, Koris A, et al. Decolonising global health: if not now, when? BMJ Glob Health 2020;5:1-4. 